\title{
Viewpoint: Sustaining rangeland landscapes: a social and ecological process
}

\author{
LYNN HUNTSINGER AND PETER HOPKINSON
}

\begin{abstract}
Authors are associate professor, Environmental and Resource Sciences/Veterinary Medicine, University of Nevada at Reno, Nev. 89512-0013; and graduate student researcher, Department of Environmental Science, Policy, and Management, University of Califormia, Berkeley, Calif. 94720.
\end{abstract}

\begin{abstract}
Sustaining rangeland ecosystems is as much a social process as an ecological one. It requires application of many of the same principles as those used in planning for wildlife reserves, but the tenets of conservation biology need to be applied to conserve social as well as ecological structural elements and processes. For some rangelands, a crucial element in a sustainable, culturally meaningful, and ecologically rich landscape is ranching, which is at once a collection of ecological processes and interactions, and an expression of human community. Results of several surveys and studies are used to highlight the "culture clashes" that occur at the ecological and social edges of landscape elements. Unfortunately, differing expectations of what conserved areas should be like has hindered the creation of alliances between environmentalists and ranchers that might prevent the degradation of the landscape by uncontrolled residential and urban development. In one California case, successful planning and alliance building led to the conservation of ranchlands. Zoning, conservation easements, political and financial support for the livestock industry, community leadership, and recognition of the heritage value of rural lifeways all played a part in this success. Similar patterns have been noted in other parts of the West. To conserve some of the most productive and biodiverse rangeland landscapes, ranching must not just be tolerated as a means to an environmental end, but valued and planned for, ecologically, socially, and economically. Rangeland professionals have an important role to play in the development of sustainable social relationships that support sustainable rangelands.
\end{abstract}

Key Words: ranching, urbanization, culture, demographic change, conservation easements, land-use planning.

The recent "sustaining rangeland ecosystems" conference in La Grande, Ore., challenged range scientists and managers to think about the future of western rangelands. The range profession arose early in this century when it became apparent that something needed to be done to care for American rangelands as they were developed economically. In recent decades, we have come to recognize the role of the range professional and range science in the management of rangelands for an increasingly broad spectrum of uses, including non-commodity values so abundant early in the century that the concept of managing for them did not often

Manuscript accepted 19 Jun. 1995. occur to early range managers. As we look to the next century, the range profession is again challenged, this time with the need to look at rangeland conservation at the landscape scale. Conserving rangeland ecosystems in the future means creating long-term alliances and agreements that cross ecological, cultural, and property lines. Our science and our skills have much to contribute to this process, as the range profession and rangelands continue to co-evolve.

Defining and building a sustainable rangeland landscape requires application of many of the same principles as those used in planning for wildlife reserves, but the tenets of conservation biology need to be applied to conserving social as well as ecological structural elements and processes. Implementing these principles also calls for the participation and cooperation of the diverse social groups that make up a rich, balanced, future landscape. We argue that one of the most crucial elements in a sustainable, culturally meaningful, and ecologically rich rangeland landscape is ranching, which is at once a bundle of ecological processes and interactions, and an expression of human community. Uncontrolled development fragments ranchlands, creating social and ecological edges that eventually diminish the rangeland ecosystem. Unfortunately, differing expectations of what conserved areas should be like has hindered the alliances between environmentalists and ranchers that might prove effective in preventing the degradation of the landscape by uncontrolled residential and urban development. In this paper we explain why ranching is a key patch in the quilt of tomorrow's sustainable rangeland landscape, and we address two major aspects to planning for such a landscape:

1.) Why planning is needed to minimize edge, maximize connectivity, and protect core areas in both ecological and social dimensions; and,

2.) How differing landscape ideologies can hinder alliances that can support, develop, and implement planning.

We examine a successful land use planning effort to conserve rangelands in California and the alliance-building between ranchers, planners, and environmentalists that made it work. Similar methods have been applied in other parts of the West.

\section{California as Case Study}

Far from being eccentric, we believe California is in several ways a harbinger of changes to come. In fact, California has con- 
tributed vast numbers of citizens to surrounding states in recent years (Starrs and Wright 1995) but even without this direct infusion the trends are familiar: rapid population growth, expanding urban areas, proliferating ranchettes, and suburban sprawl.

Half of California's 41 million ha is public land. Of the 25 million ha of land generally defined as rangeland and desert in the state, 7.5 million ha are owned by ranchers (Forero et al. 1992). Private rangelands support the highest densities and diversities of wildlife species in the state. Producing more than 10 times the forage grown on public rangelands, California's ranchlands are predominantly made up of annual grasslands, oak woodlands, and chaparral shrublands. Of these, the annual grasslands and oak woodlands provide the vast majority of the forage for livestock grazing and are overwhelmingly in private ownership. For example, of the 3 million ha of oak woodland, less than $20 \%$ is in public ownership, compared to $76 \%$ of the state's forests and $80 \%$ of the state's deserts (Ewing et al. 1988).

Shortly after the turn of the century, when California's agricultural development began in earnest, millions of acres of woodlands and grasslands were converted to crop production. Today California ranchlands are mostly in the foothills and coast ranges, where steep topography, poor soils, and limited water made crop production infeasible. In this wooded refuge, California range livestock production has continued relatively unmolested until the last decade or two. Recent demographic and technological developments are now changing this landscape.

California's population is estimated to reach 36 million by the turn of the century. Formerly confined to major transportation centers like the San Francisco Bay, the Sacramento River, and the Los Angeles basin, the urban population of the state is making rapid inroads into the foothills and coast ranges in search of less costly housing, expansive mansions, or the ranchette lifestyle. Some central Sierran foothill towns, once sleepy communities left over from the Gold Rush, are now the fastest growing cities in the state. Expanding out from the San Francisco Bay, the hills of Contra Costa, Alameda, San Mateo, Solano, Marin, and Sonoma counties are increasingly fragmented by fingers of subdivisions and clusters of ranchette developments.

All this has had tremendous and not yet fully appreciated effects on California's woodlands and grasslands. A statewide survey of oak woodland owners in 1985 and 1992 showed that the majority of ranches are now less than 5 miles from a subdivision, and that the average size of rangeland properties is shrinking (Unpublished manuscript, Huntsinger et al., Huntsinger and Fortmann 1990). The 1992 survey also revealed that more than a third of the woodlands had changed hands in 7 years, and approximately $5 \%$ were known to have been subdivided for intense residential development during that period (Unpublished manuscript, Huntsinger et al.). The pattern of urban expansion seems to be that the more level lands are developed first, with croplands close to town centers the first to be converted for housing on a large scale. As pressure intensifies, however, and as the amenity values of oak woodlands become increasingly popular, housing expands into the woodlands (Forero et al. 1992). A compilation of data from a variety of sources who calculated oak woodland extent over the years since 1932 shows what appears to be an increasing rate of decline (Fig. 1). Yet a simple assertion that so much acreage has been converted is insufficient to gauge the effect: a corona of ecological and social impacts extends from each developed edge.

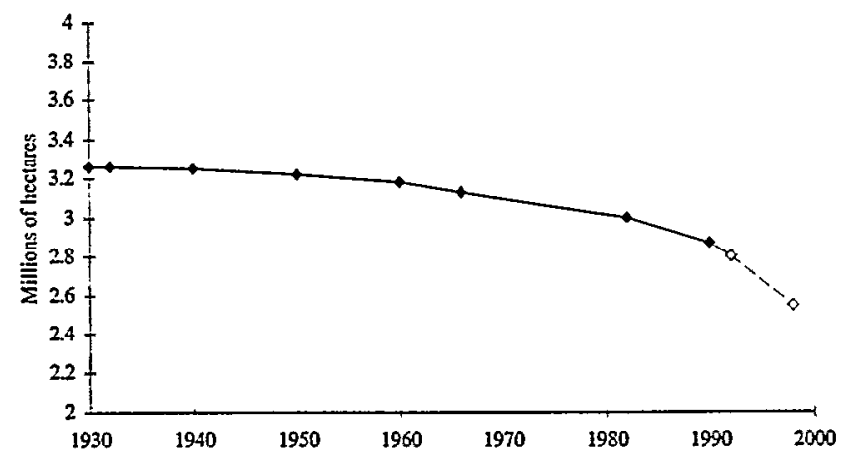

Fig. 1. Extent of Californian oak woodlands, 1932-1992 (Huntsinger, unpublished manuscript; Holzman, 1993; Huntsinger and Fortmann, 1990; Bolsinger, 1988; Ewing et al. 1988.).

\section{Ranchlands as Ecological Buffer and Cultural Preserve}

The economic imperatives for preserving rangeland livestock production in an urban state are controversial; it is the conservation imperatives that are most clearly beyond debate. Land used for ranching acts as a buffer between urban areas and wildlands, and offers high quality wildlife habitat, watershed, and open space. The problems caused by not having a buffer zone of intermediate use between national or state parks and developed areas are well documented and increasing (Huntsinger et al. 1994).

Environmental interests and public agencies simply do not have the money to buy extensive areas of private ranch land for open space and wildlife habitat, especially when they are competing with development dollars. Basic credos of conservation biology tell us that we need large core areas of habitat, and connected areas of habitat, to protect larger wildlife species and species with special needs, and to permit adequate genetic interchange. Extensive land uses like ranching supply such expanses of habitat. A ranching economy also provides a tax base, and land cared for by people not on the government payroll.

Concepts of connectivity and core for protecting reserve ecosystems apply to ranching communities: unless a "critical mass" of ranchers remains in an area, the ranching community is whittled down by incremental development to the point at which it is no longer economically viable, even for determined holdouts (Daniels 1991). Ranchers rely on other ranchers and the rural community for social as well as economic reasons, for outside jobs, informal labor pools, and support services (Smith and Martin 1972; Ellickson, 1991). In addition, as with any preserve, minimizing the amount of edge between ranchland areas and severely different land uses such as subdivision and ranchette development is important.

\section{The Issue of Edge}

Expanding land conversion has direct effect on many western ranchers. Across the West, population growth and accompanying value shifts bring people with different ways of looking at the landscape into frequent contact. The lives of urban and rural dwellers are becoming increasingly intertwined, and often tangled. The physical expression of this entanglement can be found at the urban wildland interface. 
As urban development advances into rangeland, the business and cultural practices of ranching are hampered. When ranches and suburbia meet, the resulting "clash of cultures" or lifestyles makes running a livestock operation more difficult and less profitable, increasing the likelihood that a rancher will decide to sell his land for further development (Hart 1991, Forero et al. 1992, Hargrave 1993).

Ranching at the urban-rangeland interface becomes more difficult as a result of marauding dogs, introduction of exotic plants, vandalism, trespass, carelessness with gates and fences, and increased liability costs (Hart 1991, Forero et al. 1992, Hargrave 1993). Restrictions on traditional management activities such as prescribed burning, or predator, weed, and pest control, may develop. In addition, the "impermanence syndrome" may have a demoralizing effect: anticipating seemingly inevitable development, ranchers postpone ranch improvements, and perhaps do not take good care of their land (Heimlich and Anderson 1987, Daniels 1991, Hart 1991).

New suburban neighbors too may find that their home adjoining ranch land is not as idyllic as they would like. Stray livestock may cause property and fence damage, and automobile accidents (Ellickson 1991). Slow ranch vehicles or livestock may block commuter traffic. The unaccustomed smells, noises, and other side effects of ranching can be an annoyance. Neighbors may also be concerned about the possible threat of pesticide or fertilizer residues in soil, air, and water, and water pollution from contaminated run-off. The unexpected demise of a (stray) family pet can also be a detraction.

Pervasive in the relations between ranchers and those suburbanites who live adjacent or near to ranch properties is "culture clash." Many of those moving to rural areas from cities simply do not understand the ethics or traditions of rural life, and even if they did, often do not have the resources to comply. For example, views of how to resolve disputes or work with institutions are fundamentally different. In a recent survey of ranchers in Tehama County, the majority of those surveyed said that if stray stock wandered onto their property, they would either round up the animals and return them or call the owner and discuss the procedure for rounding them up and returning them, rather than call any of the agencies or legal entities responsible for animal or livestock control (Unpublished manuscript, Huntsinger et al.). The suburbanite is used to relying on institutions and officialdom when concerned about a legal infraction such as trespassing stock. New ex-urban residents may not even be able to tell whose stock is involved when the animals wander onto the driveway or into the back yard. Yet they also do not understand the rancher's disgust when the police or animal services are contacted. Ellickson's (1991) work in Shasta County, Order Without Law, documents the tendency among ranchers to resolve disputes within their own groups through peer pressure and avoidance of outside intervention.

Despite conflicts and misunderstandings, these new neighbors share some values: both ranchers and urbanites on the edge generally share a fondness for natural landscapes. Suburbanites have often paid a premium to be at the edge. Ranchers have in many instances sacrificed opportunities for easier or more lucrative careers to stay in the country and work outside.

Suburban dwellers often appreciate having a rancher keep an eye on the open space, to prevent vandalism and other uncontrolled activities. In much of California, grazing is valued for fire control, a great concern at the wildland interface. Such common- alties can help overcome differences. In one notorious California case, affluent suburbanites living next to a state park sued when a decision was made to remove grazing because they were concerned about fire hazard (Huntsinger et al. 1994). Anticipatory planning that provided a ranchland buffer around the park would have improved the park's ecological potential and prevented a long and alienating battle between the park and local residents.

Land use planning is one way to prevent the urbanization of ranchland buffer zones. Unfortunately, ranchers are often uncomfortable with the concept. It is associated with what they perceive as an accelerating erosion of property rights. Around half of the ranchers in a recent survey of ranchers in Tehama County stated that local and statewide land use planning was a serious threat to ranching (Unpublished manuscript, Huntsinger et al.). On the other hand, the overwhelming majority wanted their ranchlands to remain in private ownership used for livestock production, and they universally objected to the prospect of residential development on their land when and if sold (Unpublished manuscript, Huntsinger et al.). Yet few wanted to see their land designated "open space," owned by a non-profit organization, or fall into the hands of a public agency. The rancher generally has a fundamental affection for the ranching lifestyle and believes that land should be used productively (Unpublished manuscript, Huntsinger et al.). Similar to the attitudes discussed in the trespass situation, in general the rancher also dislikes the involvement of outsiders, particularly agencies and bureaucracy, in land management.

Finally, land value often is a significant part of a rancher's financial portfolio. One study in the central Sierra showed that ranchers in the last decade had a higher return from land appreciation than livestock production (Hargrave 1993). But this return remains unrealized until property is sold, and it follows that a rancher can be threatened by land use restrictions and regulations that might impinge on the ultimate sale value of the land, whether or not the rancher plans to sell the property. Landowners, especially those close to retirement, are nervous about losing the right to develop their land (Gobster and Dickhut 1988). The ranch's development value may be a rancher's major equity. In the Tehama County survey, about a fifth of the ranchers indicated that they considered land appreciation an important motivation to retain their land and keep ranching. Just as many, however, indicated that an important motivation was to encourage their children to continue ranching, and about two-thirds had their land in the California Land Conservation (Williamson) Act. The Act provides tax relief to landowners who agree to keep their land in agricultural production for the next ten years (Forero et al. 1992). At the same time, two-thirds of Tehama County ranchers claimed that over-regulation was one reason they might throw in the towel (Unpublished manuscript, Huntsinger et al.).

\section{A Problem of Perception? Environmentalists and Ranchers}

In general, ranchers and environmentalists are not overjoyed with one another. Almost $90 \%$ of ranchers in Tehama County felt that "environmentalism" was a serious threat to ranching. In a 1987 survey of ranchers and environmentalists in Malheur County, Ore., the 2 groups were diametrically opposed on the issues of grazing and "wilderness designation." Environmentalists thought there was simply too much grazing going on in the coun- 
ty, while ranchers thought too much valuable rangeland was being set aside as wilderness (Huntsinger and Heady 1988). On the other hand, the great majority of Tehama County ranchers stated that "feeling close to the earth" was an important reason they kept on ranching. In the statewide surveys of oak woodland landowners, the majority of ranchers reported that being "near natural beauty" was an important reason why they chose to live and work in the woodlands (Huntsinger and Fortmann 1990).

Ranchers and environmentalists share a common joy in rangelands and nature. Why then are they so alienated from one another? We argue that the alienation arises at least partly from different expectations of nature, and that in fact, the differences between these groups arise not so much in what they want, but in what they see and in how they think about the past.

In the Malheur study, there were great differences in how ranchers, environmentalists, local community members, and BLM employees viewed conditions on the same rangelands (Fig. 2). Ranchers tended to see grazed rangelands as being in good shape, no doubt because for them, a rangeland that looks well-utilized looks good. Environmentalists, on the other hand, expect a natural area to look pristine or untouched. This expectation is unattainable on land used for livestock production. Because of this fundamental value difference, environmentalists have long dismissed the ecological values of grazed rangelands.

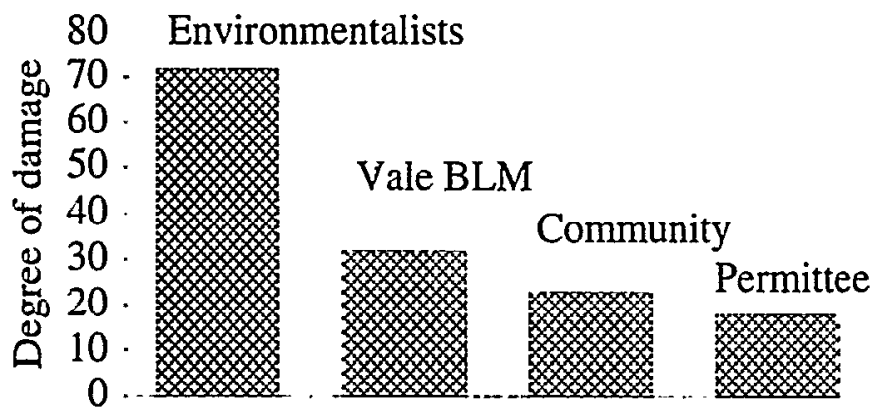

Fig. 2. Perceived degree of environmental damage on Malheur County rangelands, 1987 (Huntsinger and Heady, 1988).

A typical woodland stockpond provides another example of the difference in how the 2 groups interpret the landscape. The environmentalist sees the stockpond as a valuable wildlife habitat, a refugia being trampled and polluted by cattle. The rancher sees a structure built 30 years ago by a forbear for the express purpose of watering cows. Both groups are influenced by nostalgia for an imagined past. For the rancher, the past was a time when being a rancher meant unrestricted freedom to do as one pleased, a time when the best in American cultural values were represented by the independent, self-sufficient, and honest cowhand. The cow is a symbol of the productive use of a harsh land.

The environmentalist, on the other hand, often sees the cow as a symbol of the rapacious defilement of a glorious pristine natural wonderland, with human influence nothing but negative since settlers arrived in the West. In our view, both are nostalgic for essentially imaginary past landscapes. Nonetheless, this nostalgia pervades interpretation of natural ecosystems.

Ranchers feel threatened by the public interest in ranch lands. Ranchland, with its open, undeveloped character, appears "public" to urban visitors and suburban residents because it is a rich source of public goods. In recent decades, the public interest in extensive private properties is typified by the increasing popularity and use of the term "open space." Open space is a term designed for private lands that provide public goods and is now ubiquitous. The rancher clings to the idea that private property implies the right to do as one chooses with one's land, instead of use rights designated through social contract. How can ranchers, environmentalists, and suburbanites, each with widely divergent views of what the "right" Iandscape is and how to attain that landscape, be brought to the table? Zoning, tax relief, and conservation cascments are all tools that have been proposed for protecting the rangeland landscape.

\section{Zoning and Tax Assessment}

Zoning can offer significant protection to agricultural land when development pressures are low. Although vulnerable to changes in political climate, to the siren call of property taxes from large projects, and to legal challenges of taking, zoning can reduce development pressure as an interim measure while a more permanent land conservation solution is being devised (Atash 1987, Daniels 1991, Hart 1991). Because it is not contingent on landowner consent, zoning can protect large, contiguous areas of agricultural land and may serve as a powerful and inexpensive method of agricultural land conservation, especially if part of a region-wide plan (Daniels 1991). On the other hand, when applied without a broad consensus of support, zoning will ultimately fail as political fortunes wax and wane.

A less effective tool, primarily intended for promoting agricultural production but with land conservation potential, is tax relief such as the Williamson Act. Although California counties with firm zoning regulations and comprehensive planning have had success with the Williamson Act (McClaran et al. 1985), value tax assessment has proved largely ineffective at the urban-rangeland boundary because development opportunities are so enticing (Atash 1987, Daniels 1991, Forero et al. 1992) and conflicts at the urban wildland interface so burdensome. However, Hargrave (1993) concluded, at least for El Dorado County, that by reducing the cost of ranching, the Williamson Act "more than any other factor makes ranching viable and is responsible for keeping the county's rangeland in agriculture." Tax relief may act to protect rangeland ecosystems, open space, and ranching culture, but again, only when development pressures are low.

\section{Property Concepts and Conservation Easements}

For long-term conservation of rangeland ecosystems, the ranching community will have to modify some strongly-held beliefs about property rights. Most people conceive of their property as the actual land they own, the ground upon which they walk. In legal terms, however, property is not the physical land but various rights to the land agreed upon by social contract (Macpherson, 1978, is a classic treatment of this topic). Each of these rights-the mineral rights, the timber rights, the right to sell, the right to develop-may be treated and disposed of separately (Atash 1987, Daniels 1991, Wright 1993). Selling or donating a conservation easement precludes development in perpetuity but leaves other property rights intact. A rancher still owns the land and can sell it or continue a livestock operation. 
Conservation easements address rancher concerns about their financial stake in the land by providing either income and estate tax deductions for the donation of an easement or a potentially large percentage of the fee simple price for the sale of an easement (Daniels 1991, Wright 1993). Money from a sale can be put toward new equipment or stock, ranch improvements, or debt payment; estate tax deductions can make it easier for a rancher to pass the ranch along to offspring (Daniels 1991). After the sale of development rights, property tax is calculated based on the agricultural value of the land (Wright 1993).

Evidence suggests that some ranchers are willing to forego the full development value of their land in exchange for partial compensation and the opportunity to preserve the range and continue their way of life. Smith and Martin (1972) found that ranchers in Arizona resisted selling ranches at market prices far exceeding their value as livestock operations for reasons that included "love of the land" and "love of rural values." More recently, Hargrave (1993) suggested that ranchers in El Dorado County, Calif., continue to ranch in the face of economic hardships and development pressure because they enjoy the tradition and the way of life and want their children to be able to ranch as well. A 1994 survey of Tehama County, Calif., ranchers revealed that approximately 5\% had their land in conservation easements (Unpublished manuscript, Huntsinger et al.).

\section{The Need for Alliances}

Alliances between groups are key to creating a sustainable ranchland landscape. Land use planning and zoning are only stop-gap measures. Landscape conservation strategies require broad political support and local participation. This includes urban-based and local environmentalists who can bring considerable financial and political power to efforts to fund permanent conservation easements and development rights swaps, as well as the ranchers who actually own and manage the land.

Environmentalists, suburbanites, and ranchers hold some common attitudes towards the land, but they also have cultural differences that hinder alliances. Intercultural communications theory suggests that differences can be bridged using the "cultural convergence model" of communication (Simcox and Hodgson 1993). Aiming toward a "merging of values and achievement of mutual understanding" between 2 cultures, the cultural convergence model stresses personal communication and reciprocal acceptance of the "cultural norms, standards, values, and meanings" of the other group (Simcox and Hodgson 1993). Generally, one "culture" must take the first step in making friendly overtures to the other group, and as face-to-face communication increases so too should "cultural convergence" and the possibility of alliancebuilding. Simcox and Hodgson highlight the central role that social networks play in intercultural communication and the effective dissemination of information between cultures. The history of Marin County's rangeland protection efforts has much in common with this model, and illustrates the roles of zoning, planning, and easements in landscape conservation strategy.

\section{Conservation of Rangeland in Marin County, California}

Described in John Hart's Farming on the Edge (1991), Marin County ranchers, environmentalists, and planners successfully implemented a permanent rangeland conservation program based on compromise, trust, communication, and mutual interest in protecting Marin's rangeland ecosystems, open space, and the ranching way of life.

Immediately north of San Francisco, Marin County today comprises a highly-developed urban corridor to the east and a rangeland agricultural zone to the west grazed by about 13,000 dairy cattle, 9,000 beef cattle, and 11,000 sheep. Marin's dairies are unusual, more ranches than modern dairies, because a major part of the feed supply for these small-scale, family operations is natural dryland range. The agricultural zone serves as an extensiveuse buffer between the county's urban area and Point Reyes National Seashore and Golden Gate Recreational Area, providing significant open space values and protection to oak woodland and grassland ecosystems. In the late 1960 s however, urbanization of western Marin seemed inevitable. Planners and ranchers alike assumed Marin's faltering ranches would soon be sold and subdivided, bringing suburbia right up to the borders of the National Seashore. In response to this vision of urban sprawl, conservation-minded county planners and environmentalists from urban Marin pushed through a minimum lot-size zoning ordinance to counter the pressure of rapidly escalating land prices by creating lots large enough to discourage development. Zoning, however, proved only a first and impermanent line of defense.

\section{Alliances Form}

Initially, nearly all Marin's ranchers adamantly opposed the new zoning ordinance as a gross violation of property rights. An important exception was the president of the local Farm Bureau who foresaw that if ranching of any kind was to have a future in Marin, protection of its land base from development was imperative. In the years following, his advocacy of the zoning ordinance and his subsequent role in alliance-building with urban environmentalists proved instrumental in persuading the ranching community that conservation-based planning was in their best interest.

Zoning provided temporary protection for Marin's rangeland. By the mid-1970s, it was apparent that, for 3 primary reasons, Marin County needed a more lasting solution: 1.) there were ample numbers of wealthy buyers willing to purchase large parcels for non-agricultural purposes; 2 .) the zoning ordinance remained ever vulnerable to political changes on the County Board of Supervisors; and 3.) if Marin's dairy industry were to fail, alternative profitable uses of the land would be difficult under the zoning ordinance, making it likely that "takings" challenges would ensue.

Urban environmentalists realized that if ranching withered, open space would inevitably dwindle. If Marin was to retain its rangeland, a first priority was to sustain the dairy ranches, because they are critically dependent on having enough operations to support the local creamery. Support took tangible forms, including large subsidies for water delivery during drought years and for state-mandated runoff control ponds, and political championing in battles with regulatory agencies. Tentative communication began between the 2 groups, and after the clear show of support, environmentalists, ranchers, and county planners began to put their differences aside and form alliances directed toward long-term conservation of the agricultural zone. A strategy developed for a permanent solution to urban encroachment: the pur- 
chase of ranch conservation easements by a local land trust, the Marin Agricultural Land Trust (MALT). The substantial funds required for easements on these exceptionally valuable lands came from a local private foundation called the Buck Trust, the California Coastal Conservancy, a state agency, and from a statewide conservation bond issue.

\section{Working Towards Permanence}

Despite some serious misgivings, many Marin dairy, beef, and sheep ranchers have agreed to sell or donate conservation easements to MALT. As of January 1995, the Trust holds easements on 10,321 ha (Personal communication, MALT). Most within the Marin ranching community have come to realize that protection from development is in their own interest and in the interest of the industry as a whole (see also Daniels 1991). Now that widespread development in the agricultural zone is stymied, the critical mass of dairy ranches necessary for the survival of the dairy industry seems assured. Land prices are once again within the budgets of ranchers wishing to expand operations or ranchers' kids wishing to enter the family business. With a more secure future, ranchers are inclined to invest in long-postponed ranch improvements. From a cultural perspective, the land and the life they love will endure.

Urban environmentalists in Marin have had to discard some cherished beliefs about the intolerable effects of ranching on rangeland ecosystems. Initially, support for agriculture in western Marin was merely a means to the end of preserving open space in the county. With exposure to ranchers and their way of life, many environmentalists now support ranching, at least on the familyfarm scale, as a productive and worthy activity in itself and as generally compatible with environmental and open space goals. A hint of "cultural convergence" may be discerned, as environmentalists come to value ranching culture as an important part of Marin's social character. Admiration is not universal; at least one major environmental group, with mostly non-local membership, continues to view ranching and conservation as incompatible.

\section{Requirements for Success}

Only minutes from San Francisco, it is possible to come around a bend in the highway and see only a bucolic pastoral landscape from one horizon to another in western Marin County. Holding together the ranching landscape are well-established networks for communication among committed ranchers, local residents, rangeland professionals, and environmentalists. The county is both socially and ecologically well equipped to tackle and resolve future water quality and resource management issues. Marin succeeded in constructing a sustainable rangeland landscape because (Hart 1991):

1.) restrictive zoning imposed by urban environmentalists on unwilling ranchers halted development, giving alliances time to form and start work. Without this initial show of urban force, subsequent collaboration would have had little rangeland left to conserve. Yet without the additional cooperative alliance building, restrictive zoning would have rapidly broken down;

2.) urban environmentalists and county planners jettisoned ideas about the incompatibility of ranching and open space ecosystems and initiated communication with ranchers; and, importantly, were willing to support the ranching industry politically and financially;

3.) leaders of the local Farm Bureau and other rancher groups were willing to collaborate with environmentalists and county planners. Local networks like the Farm Bureau and Cattlemen's Association are essential for disseminating information and persuading landowners of the value of conservation-based planning. Environmental groups serve a similar function for their constituency;

4.) the Marin dairy industry, the infrastructure underpinning much of the county's ranching, remained viable;

5.) sources of funding for the purchase of conservation easements were available.

It is important to emphasize that zoning, conservation easements, and other rangeland conservation methods must be developed within the context of a comprehensive, conservation-based regional plan (Atash 1987, Daniels 1990, Daniels 1991, Fulton 1993). Haphazard checkerboarding of developed land next to protected land is of minor benefit to ecosystem function and wildlife habitat, and exacerbates social conflict. Being voluntary, conservation easements can result in such checkerboard landscapes if clumsily planned (Daniels 1991). Zoning to consolidate development and a regional plan to direct easement purchase and donation efforts can prevent such a waste of resources.

\section{Conservation Easements in the Rocky Mountains}

The Rocky Mountain region has also seen rancher-environmentalist collaboration and notable use of the conservation easement (Miller and Wright 1991, Wright 1994). As in California, rampant suburban development has consumed prime Rocky Mountain rangeland, especially around Denver and Boulder. Ranchers are concerned at the loss of the land base, rising land values, and the heavy tax burdens their children will face when inheriting the family ranch. Ranchers share some concerns of environmental groups regarding destruction of wildlife habitat, extinction of plant and animal species, and loss of open space. Over the past decade, ranchers have donated or sold conservation easements on over 60,700 ha of rangeland in Montana and Colorado to local land trusts, protecting the agricultural resource, key range and riparian habitat, and open space (Miller and Wright 1991, Wright 1994). Conservation easements appear to have succeeded where regulatory systems of land use control have often proved ineffective. Miller and Wright (1991) suggest that this is because the voluntary nature of easements necessitates collaboration.

\section{Conclusions}

Can these models work elsewhere? Planning tools like zoning, use value tax assessment, and conservation easements are widely available, although the particulars vary. But collaboration between ranchers, environmentalists, and planners is essential to success-sustainable social relationships are the key to our future rangeland landscape. Range professionals and scientists have an important role to play by providing and developing good information about ecological systems and management options, and 
by using their communications skills to help groups find a "cultural convergence." Information about how management strategies can solve some rangeland problems can help defuse controversies fueled by emotion and misunderstanding. When groups work together rather than fight each other, when the sharp edges of ecological and social conflict are minimized or softened by compromise and planning, ranchlands and rangelands have the best chance of long-term survival.

In sum, to conserve many western rangeland landscapes environmentalists will need to give a bit on their expectations of conserved areas, while ranchers may have to reconfigure slightly their concepts of what it means to own property. Rangeland managers can help facilitate a meeting of the minds if they recognize and understand the legitimacy of each group's claims. The skills needed to facilitate the development of sustainable agreements need to be part of today's range management curriculum.

Ranching and environmentalist communities should not let polarization over land management practices prevent steps to protect rangelands from poorly planned development: debates over the ecological impacts of grazing on rangelands or the imperatives of wildlife management should not be rendered moot by the replacement of grass with cement and riparian areas with culverts. As Michael Farrow, Program Director of the Department of Natural Resources of the Confederated Tribes of the Umatilla Indian Reservation said at the recent conference in $\mathrm{La}$ Grande: "Something has to be done about this urban sprawl. It is wasteful. It's a mistake our children will be paying for, and their children after that, and so on for generations."

\section{Literature Cited}

Atash, F. 1987. Urban growth and farmland preservation: an assessment of alternative programs, p. 199-208. In: W. Lockeretz (ed.), Sustaining agriculture near cities. Soil and Water Conserv. Soc., Ankeny, lowa.

Bolsinger, C. 1988. The hardwoods of California timberland, woodland, and savannahs. USDA For. Serv., Pacific NW For. and Range Exp. Sta. Portland, Ore.

Daniels, T.L. 1990. Using LESA in a purchasc of development rights program. J. Soil and Water Conserv. 45:617-621.

Daniels, T.L. 1991. The purchase of development rights-preserving agricultural land and open space. J. Amer. Planning Assoc. 57 $421-431$.

Ellickson, R.C. 1991. Order without law: how neighbors settle disputes. Harvard Univ. Press, Cambridge, Mass.

Ewing, R., N. Tosta, L. Huntsinger, R. Tuazon, R. Marose, R. Motroni, K. Nielson, and S. Turan. 1988. California's forests and rangelands: growing conflict over changing uses. Assessment prepared for the California State Board of Forestry and the State Legislature. Anchor Press, Sacramento, Calif. 348pp.

Forero, L., L. Huntsinger, and W.J. Clawson. 1992. Land use change in three San Francisco Bay Area counties: implications for ranching at the urban fringe. J. Soil and Water Conserv. 47:475-480.

Fulton, W. 1993. Sliced on the cutting edge: growth management and growth control in California, p. 113-126. In: J.M. Stein (ed.), Growth management: the planning challenge of the 1990's. Sage Publications, Newbury Park, Calif.

Gobster, P.H. and K.E. Dickhut. 1988. Factors influencing landowner acceptance of open space preservation methods. Soc. and Nat. Res. 1:351-364.

Hargrave, T. 1993. The impact of a federal grazing fee increase on land use in El Dorado County, California. Master's Project. Energy and Resources Group, Univ. California. Berkeley. 68pp.

Hart, J. 1991. Farming on the edge. Univ. of California Press, Berkeley. $174 \mathrm{pp}$.
Heimlich, R.E., and W.D. Anderson. 1987. Dynamics of land use change in urbanizing areas: experience in the Economic Research Service, p. 135-154. In: W. Lockeretz (ed.), Sustaining agriculture near cities. Soil and Water Conserv. Soc., Ankeny, Iowa.

Holzman, B. 1993. Vegetation change in Californian oak woodlands. $\mathrm{Ph}$. D. Diss., Dep. of Forestry and Resource Manage.., Univ. of California, Berkeley. 215pp.

Huntsinger, L. and H.F. Heady. 1988. Perceptions of the Vale program, p. 103-133. In: H.F. Heady (ed.), The Vale Rangeland Rehabilitation Program: an evaluation. Resour. Bull. PNW-RB-157. USDA For. Serv., Pacific NW Res. Stn.; USDI Bur. of Land Manage., Portland, Ore.

Huntsinger, L. and L.P. Fortmann. 1990. California's privately owned oak woodlands - owners, use, and management. J. Range Manage. 43: 147-152.

Huntsinger, L., L. Buttolph, and J. Fried. 1994. The ranger, the rancher, and the rolex: conflict over grazing at Mt. Diablo State Park, CA. Environ. and Natural Resources, Utah State Univ.

Macpherson, C.B., (ed.). 1978. Property-mainstream and critical positions. Univ. of Toronto Press, Toronto, Canada. 138pp.

McClaran, M.P., J. Romm, and J.W. Bartolome. 1985. Differential farmland assessment and land use planning relationships in Tulare County, Califomia. J. Soil and Water Conserv. 40:252-255.

Miller, A.P. and J.B. Wright. 1991. Report of the Subcommittee on Innovative Growth Management Measures: preservation of agricultural land and open space. The Urban Lawyer 23:821-844.

Simcox, D.E. and R.W. Hodgson. 1993. Strategies in intercultural communication for natural resource agencies, p. 123-134. In: A.W. Ewert, D.J. Chavez, and A.W. Magill (eds.), Culture, conflict, and communication in the wildland-urban interface. Westview Press, Boulder, Colo.

Smith, A.H. and W.E. Martin. 1972. Socioeconomic behavior of cattle ranchers, with implications for rural community development in the West. Amer. J. Agr. Econ. 54:217-225.

Starrs, P. and J.B. Wright. 1995. Great Basin growth and the withering of California's Pacific Idyll. Geographical Review. 85:224-244.

Wright, J.B. 1993. Conservation easements: an analysis of donated development rights. J. Amer. Planning Assoc. 59:487-493.

Wright, J.B. 1994. Designing and applying conservation easements. J. Amer. Planning Assoc. 60: 380-388. 